Maurer School of Law: Indiana University

Digital Repository @ Maurer Law

\title{
Through the Quarantine Looking Glass: Drug-Resistant Tuberculosis and Public Health Governance, Law, and Ethics
}

\author{
David P. Fidler \\ Indiana University Maurer School of Law, dfidler@indiana.edu \\ Lawrence O. Gostin \\ Georgetown University Law Center \\ Howard Markel \\ University of Michigan - Ann Arbor
}

Follow this and additional works at: https://www.repository.law.indiana.edu/facpub

Part of the Health Law and Policy Commons, Medical Jurisprudence Commons, and the Public Health Commons

\section{Recommended Citation}

Fidler, David P.; Gostin, Lawrence O.; and Markel, Howard, "Through the Quarantine Looking Glass: DrugResistant Tuberculosis and Public Health Governance, Law, and Ethics" (2007). Articles by Maurer Faculty. 371.

https://www.repository.law.indiana.edu/facpub/371

This Article is brought to you for free and open access by the Faculty Scholarship at Digital Repository @ Maurer Law. It has been accepted for inclusion in Articles by Maurer Faculty by an authorized administrator of Digital Repository @ Maurer Law. For more information, please contact rvaughan@indiana.edu. 


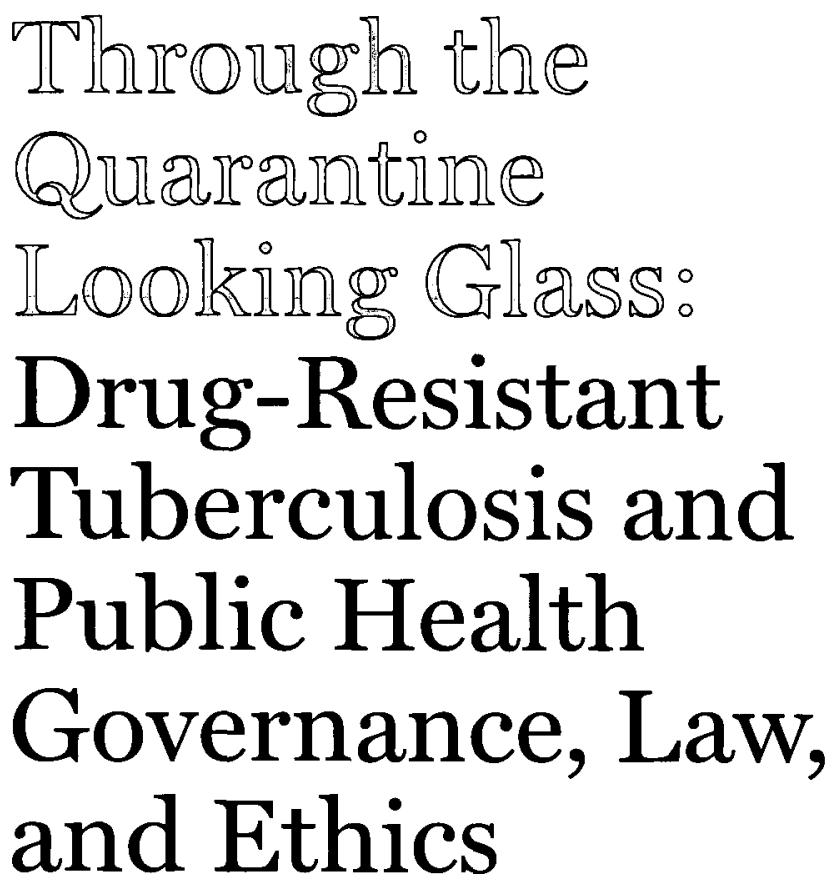

David P. Fidler, Lawrence O. Gostin, and Howard Markel

\section{Introduction}

Dramatic events involving dangerous microbes often focus attention on isolation and quarantine as policy instruments. The incident in May-June 2007 involving Andrew Speaker and drug-resistant tuberculosis (TB) joins other communicable disease crises that have forced contemplation or actual application of quarantine powers. Implementation of quarantine powers, which encompasses authority for both isolation and quarantine actions, is important not only for the handling of a specific event but also because the use of such authority provides a window on broader issues of public health and the legal rules, ethical principles, and governance systems that support it. Debates about quarantine powers reflect political and social attitudes about public health that often tell us more about this policy endeavor than acts of isolation and quarantine themselves.

This article uses the Speaker incident to explore how isolation and quarantine authority provides a lens through which to assess public health commitments, competencies, and capabilities. We describe the Speaker incident itself, which played out in national and global media in revealing and disturbing ways. Much of the controversy focused on the application of federal quarantine powers, so the incident connects to the larger political, governance, and legal issues quarantine authority raises. We analyze quarantine powers by reflecting on some historical manifestations and by exploring the current state of isolation and quarantine authority in public health law and ethics in the United States. The article's final section looks beyond the question of quarantine powers in the United States to consider global implications of the Speaker case, including the challenges of addressing the growing problem of drug-resistant TB.

David P. Fidler, J.D., M. Phil., is the James Louis Calamaras Professor of Law and the Director of the Center on American and Global Security at Indiana University, Bloomington. Lawrence O. Gostin, J.D., LL.D., (Hon.), is the Associate Dean (Research and Academic Programs) and the Linda D. and Timothy J. O'Neill Professor of Global Health Law at Georgetown University Law Center in Washington, D.C. He is also a Professor of Public Health at the Johns Hopkins University in Baltimore, Maryland and a Visiting Professor at Oxford University. Howard Markel, M.D., Ph.D., is the George E. Wentz Professor of the History of Medicine and the Director of the Center for the History of Medicine at the University of Michigan. 


\section{The Andrew Speaker Incident: Background and Overview}

Background to the Speaker Incident: Rise of Concern about Drug-Resistant TB

For many in the United States, Andrew Speaker's odyssey represented their first exposure to multi-drug resistant TB (MDR-TB) and extensively drug-resistant TB (XDR-TB) and the potential need for public health officials to exercise quarantine powers to address these threats. While TB is treatable with the first-line drugs isoniazid and rifampicin, MDR-TB is resistant to them. ${ }^{1}$ XDR-TB is also resistant to isoniazid and rifampicin, to any fluoroquinolone, and to at least one of the three injectable second-line drugs: amikacin, kanamycin, and capreomycin. ${ }^{2}$

Speaker's situation did not, however, arise in a vacuum. Public health awareness about the growing MDR-TB and XDR-TB problems was rising in 2006, as evidenced by the issuance of a global alert about XDR-TB by the World Health Organization (WHO). ${ }^{3}$ This alert came after analysis of new surveillance data that indicated XDR-TB was a widespread and growing problem around the world, but particularly in Eastern Europe, South Africa, and Asia. ${ }^{4}$ The data on XDRTB's prevalence, and the lack of treatment options, raised the question whether public health authorities needed to consider compulsory measures, including isolation, to contain its spread and impact on population health. ${ }^{5}$ This issue was significant enough for the WHO to issue, in January 2007, guidance on human rights and involuntary detention as an XDR-TB control strategy. ${ }^{6}$ Thus, even before Speaker became a household name, public health officials were worried about MDR-TB and XDR-TB and were, in connection with XDR-TB, anticipating the possible need to exercise quarantine powers against infected persons.

\section{Overview of the Speaker Incident ${ }^{7}$}

In the same month, January 2007, in which the WHO issued guidance on involuntary detention and XDRTB, Andrew Speaker underwent a chest X-ray and CT scan, which revealed an abnormality in his lungs. His sputum smear tested, however, negative for TB. In March 2007, Speaker had a diagnostic bronchoscopy, tested positive for TB, and was prescribed a standard regimen of first-line anti-TB drugs. The positive TB result was confirmed in April, and the Georgia Public Health Laboratory (GPHL) began testing Speaker's TB isolate for susceptibility. On April 25, Speaker reported to the Fulton County TB Clinic and advised it of his plans for traveling overseas in May, and the clinic asked for the susceptibility testing to be expedited. The next day the GPHL began susceptibility testing, and the U.S. Centers for Disease Control and
Prevention (CDC) received samples for susceptibility testing on April 27.

Between April 30 and May 9, susceptibility testing at the GPHL indicated that Speaker had MDR-TB. On May 10, Speaker, his family, private physician, and the Fulton County Health Department (FCHD) met to discuss his MDR-TB infection. At this meeting, Speaker was told not to undertake his international travel, scheduled to start on May 14. Also on May 10, the FCHD began to review legal options for restricting a patient infected with untreated MDR-TB, and, on May 10-11, the Georgia Department of Public Health (GDPH) and the CDC discussed options for restricting the travel of a person harboring untreated MDR-TB. On May 11-12, the FCHD attempted to hand-deliver a written advisory to Speaker concerning his MDT-TB infection but could not locate him.

Unbeknownst to any public health official, Speaker had, on May 11, advanced his departure date from May 14 to May 12, and he departed Atlanta for Europe on May 12. On May 18, the GPDH notified the CDC that Speaker had traveled internationally, and the CDC began the effort to locate him in Europe. CDC tests of samples from Speaker indicated on May 22 that he had XDR-TB, and, on the same, day, U.S. Customs and Border Protection initiated a nation-wide border alert for Speaker based on information provided by the CDC.

The CDC tracked Speaker down in Rome on May 22 (May 23 in Rome), informed him of the XDR-TB diagnosis, and told him not to travel on commercial aircraft because he posed a significant threat to other people. Speaker indicated to the CDC he would stay in Rome while the CDC explored options for managing his infection and transporting him back to the United States. However, Speaker instead flew to Prague, Czech Republic on the morning of May 24, and then flew from Prague to Montreal later that day. On May 24, unable to locate Speaker, the $\mathrm{CDC}$ requested that the U.S. Transportation Security Administration issue an order to prevent Speaker from boarding any U.S. bound flight, and the CDC notified the Italian Ministry of Health. Also on May 24 (May 25 in Europe), the U.S. Department of Health and Human Services (DHHS) notified the WHO that Speaker's situation may constitute a public health emergency of international concern under the International Health Regulations (2005).

On May 25, Speaker re-entered the United States from Canada by automobile, and, despite being aware of the border alert, the border guard allowed Speaker into the United States. The CDC located Speaker by cell phone in New York State, ascertained Speaker's location, and ordered him to drive to Bellevue Hos- 
pital in New York City for clinical evaluation and federally mandated isolation. Upon arrival at Bellevue Hospital, the CDC served him a provisional federal quarantine order - the first such federal order since 1963. Speaker was isolated in a secure ward, where he underwent clinical evaluation to ascertain the status of his infection. After interviewing Speaker, the CDC began the process of contact tracing passengers on flights taken by Speaker, which required the cooperation of international, federal, state, and local health authorities.

While under the federal isolation order, Speaker elected to return to Atlanta on May 28, after which time his story began to appear in the media. Undisputed facts about his case, and diverging positions aired in the media, gained attention, and generated controversy about what had happened, what had gone wrong, and who was to blame. Through his own resources, Speaker was transferred on May 31 from Atlanta to the National Jewish Medical Center (NJMC) in Denver for treatment of his XDR-TB. The
Media attention was drawn back to the case when tort litigation against Speaker was initiated in Montreal in mid-July by passengers who traveled with him from Prague to Montreal. Speaker had surgery at the end of July 2007 to remove a portion of a lung infected with the MDR-TB, and, after the surgery, he was declared non-contagious and released from the NJMC on July 26, after which he flew home to Atlanta.

\section{Quarantine in History: More than a Medical Matter}

Recitation of key facts in the Speaker case does not, however, capture the emotions, controversies, and accusations it generated. The believed presence of XDR-TB, the scope of the international travel, the behavior and claims of the infected individual, the reactions of public health authorities, the failure of border control mechanisms, and the utilization of federal quarantine powers combined to heighten the significance of this incident for every level of public health policy and practice.

\section{Although the application of federal public health authority does not exhaust the complexities of Speaker's case, the use of federal quarantine power became this incident's gravitational pull in terms of attention and controversy. The exercise of such authority became important not only in its own right but also because it highlighted issues confronting public health that deserve greater attention. The exercise of quarantine power in the Speaker case became a looking glass for examining public health law, ethics, and governance in the early 21 st century.}

CDC rescinded the federal isolation order on June 2 when the Denver County Health Department placed Speaker under its isolation order.

Controversy about Speaker's case continued after his transfer to Denver because his statements did not mirror the facts presented in the CDC briefings. These divergent positions were aired in hearings Congress held on June 6, at which CDC Director Dr. Julie Gerberding and Speaker (via telephone) testified. Controversy about the Speaker incident flared again when the NJMC and CDC announced on July 3, after the results of further tests, that Speaker did not have XDR-TB but MDR-TB. This announcement gave Speaker the opportunity to continue his criticism of the CDC. It also required the CDC to explain why the new diagnosis would not have changed actions vis-à-vis Speaker because of the danger untreated MDR-TB poses to public health, especially with respect to long-distance air travel.
For many, the exercise of federal quarantine powers was the development that brought all the elements of the episode into focus and generated questions for individuals, public health officials, and governments. Although the application of federal public health authority does not exhaust the complexities of Speaker's case, the use of federal quarantine power became this incident's gravitational pull in terms of attention and controversy. The exercise of such authority became important not only in its own right but also because it highlighted issues confronting public health that deserve greater attention. The exercise of quarantine power in the Speaker case became a looking glass for examining public health law, ethics, and governance in the early 21 st century.

The idea that involuntary detention for public health purposes reflects political and social phenomena beyond breaking the chain of pathogen transmission is, of course, not new. One common response to 
epidemics, across time and national boundaries, has been the use of individual and group control measures. ${ }^{8}$ If we look at isolation and quarantine actions as part of the progression of an epidemic, we can detect impulses that often help shape it. These include the following: (1) avoiding the ill, or those perceived to be ill, particularly if the disease is thought to be contagious; (2) negotiations over how experts and the community at large understand the disease, especially in terms of cause, prevention, and amelioration; (3) the complex political, economic, and social battles that guide or obstruct a community's efforts to respond to the epidemic; and (4) the extent to which ethnicity and perceptions about a social group associated with a disease frame the responses that shape control measures aimed at individuals or communities.

Many societies have responded to visitations of contagious diseases by avoiding and isolating the ill. The Old Testament records involuntary detention and social distancing and their corresponding sanitary procedures, ${ }^{9}$ including the use of the ram's horn or shofar, traditionally sounded during the Jewish High Holidays, to signal a case of diphtheria or other contagious disease in the community. In ancient Greece, the writings of Thucydides (c. 460-c. 400 B.C.) and Hippocrates (c. 460-c. 370 B.C.) demonstrated that Greek societies attempted to avoid contact with the contagious. ${ }^{10}$ The Roman authority on medicine, Galen of Pergamon, warned that specific diseases made it "dangerous to associate with those afflicted." In A.D. 549, the Byzantine emperor Justinian enacted one of the first laws requiring restraint and isolation of travelers from regions where the plague was known to be raging. Similar forms of detention for plague directed against sailors and foreign travelers were also practiced in seventh-century China and other parts of Asia and Europe during the Middle Ages. Not surprisingly, these quarantine actions recognized the relationship between epidemic disease transmission and human movement and migration. ${ }^{12}$

The word quarantine originates from the Italian words quarantenara and quaranta giorni, which referred to the 40-day period during which Venice isolated ships before their goods, crew, and passengers could disembark during the plague-ridden days of the 14th and 15th centuries. In about 1374, Venice enacted its 40-day quarantine regulation, and, in 1403, the municipality established the first maritime quarantine station, or lazaretto, on the island of Santa Maria di Nazareth. From medieval times on, shutting the gates of a city or port to those suspected of being ill, and isolating sick people within, represented the best, and often the only, means for stemming an epidemic.
The growth of international commerce and travel during the Renaissance and the subsequent three centuries contributed to the spread of infectious diseases around the globe. To prevent the entry of contagion, sanitary cordons (literally a ring of armed soldiers guarding against entry of diseased persons) and quarantines were used in France, Britain, Austria, German, Russia, and other European and Asian nations from the 14th through 19th centuries. ${ }^{13}$ By the mid1800 s, in response to devastating cholera and plague epidemics imported into Europe from Turkey and Egypt, and the economic burdens created by different national quarantine systems, European nations with the strongest commercial or colonial interests began to engage in international cooperation. ${ }^{14}$ These efforts included attempts to harmonize quarantine policies, a process aided by the emergence of the germ theory of disease in the late 19th century..$^{15}$ Commencing in 1851, these International Sanitary Conferences continued well into the 20th century, ${ }^{16}$ generated the first uses of international law for public health purposes, and led to the creation of the first international health organizations. ${ }^{17}$

The history of quarantine, including attempts to harmonize its application, demonstrates that quarantine has had different meanings to different peoples. The interdependence of the medical understanding of contagious diseases and social control measures seems intuitive, but past epidemics suggest a more complex interaction of medical knowledge and the actual practices of disease control, revealing in the application of isolation and quarantine a complex mixture of scientific, political, economic, and social factors. This mixture reveals much about the way a society constructs its responses to infectious diseases and thus makes isolation and quarantine measures a reflection of a community's make-up and evolution.

During the first half of the 19th century in the United States, for example, the notion that a microbe might cause an epidemic was not widely accepted by medical experts or the public. Anti-contagionists held that changes in the atmosphere and environmental sources of filth (e.g., human and animal waste) caused diseases. Under this view, the "cure" was cleaning up the environment. The anti-contagionist perspective conveniently supported the opposition of merchants and traders to the burdens national quarantine systems imposed on commerce. Similarly, some countries favoring the theory of contagion and the practice of quarantine worried about the growth of the economic and political power of nations, such as Great Britain, seeking to pare back the impact of national quarantine policies on their international economic activities. 
Medical and economic dogma and political interests were not, however, always anti-quarantine. Scientific doctrine and economic attitudes proved more flexible in practice than in theory. Isolation and quarantine measures were often mounted by governments that did not subscribe to the germ theory of disease and that supported trade expansion. Epidemics of yellow fever in the United States during the late 18th and early 19th centuries - a period of devout anti-contagionism among medical professionals - often inspired some quarantine regulations.

When studying the history of social control measures as responses to epidemics in the United States over the past two centuries, a strong leitmotif is the use of such measures as a medical rationale to isolate and stigmatize groups reviled for other reasons. David Musto asserts that isolation and quarantine actions constitute more than the mere "marking off or creation of a boundary to ward off a feared biological contaminant lest it penetrate a healthy population" because one cannot consider quarantine as merely disease control without minimizing the "deeper emotional and broadly aggressive character" of a policy that separates persons from the community. ${ }^{18}$ The blame, stigma, and ostracism associated with isolation and quarantine are especially real for diseases linked to the poor, aliens, or the disenfranchised: "When an epidemic illness hits hardest at the lowest social classes or other fringe groups, it provides that grain of sand on which the pearl of moralism can form." 19

\section{Quarantine Governance and Public Health Law and Ethics}

The manner in which quarantine powers have been intertwined with religious, political, economic, and social practices, interests, values, and prejudices makes quarantine authority an important governance topic. Isolation and quarantine involve the compulsory application of public authority to individuals or groups and, thus, these acts create tensions between protecting population health and respecting individual autonomy and dignity. These tensions stimulate the heightened interest isolation and quarantine trigger, as seen in Speaker's case. Principles in public health law and ethics shape the governance task of managing those tensions, and these principles provide insight into how societies organize and perceive the use of the power to implement isolation and quarantine measures.

Isolation and Quarantine Distinguished and Defined From a governance perspective, delineation of the different facets of a government's quarantine powers is important legally and ethically. These powers encom- pass the authority to detain persons involuntarily for public health purposes. Although isolation and quarantine are often used interchangeably, they are not the same. Quarantine involves the restriction of the movement of persons who have been exposed, or potentially exposed, to infectious disease, during the period of communicability, to prevent transmission of infection during the incubation period. ${ }^{20}$ Quarantine seeks to prevent the spread of dangerous, highly contagious pathogens, such as smallpox, plague, and Ebola fever, particularly if medical countermeasures are ineffective or unavailable.

Isolation involves separating, for the period of communicability, known infected persons from the community so as to prevent or limit the transmission of the infectious agent. ${ }^{21}$ Modern science and medicine can usually detect whether a person has an infectious condition. Accordingly, isolation often is the action taken rather than quarantine, and this outcome is particularly true for TB. Isolation is, where possible, linked to treatment, including directly observed therapy (DOT) for $\mathrm{TB}$, which the detaining authority offers to, or imposes on, persons subject to isolation orders. ${ }^{22}$

\section{Jurisdictional Complexities Involving Isolation and Quarantine Actions}

Public health authorities possess a variety of powers to restrict the autonomy or liberty of persons who pose a public health threat because they are infected with, or have been exposed to, dangerous, contagious pathogens. These authorities can direct individuals to discontinue risk behaviors (e.g., "cease and desist" orders), compel them to submit to physical examination or treatment, and detain them using public health or criminal justice powers. ${ }^{23}$

Legal authority to exercise these powers in the United States can be found at local, state, and federal levels. These jurisdictional levels generate federalism questions: what level of government may apply which rules in what situations? Answers to these questions depend on the origin and extent of the public health threat. Local and state laws apply if the threat is confined to a city, county, or state. If the threat is imported from a foreign country, or if the pathogen is being transmitted across state lines, then federal law applies.

When it comes to the exercise of isolation and quarantine powers, reality tends to be messier than the conceptual realm. Public health officials need clear lines of authority in emergency situations, often the moments when isolation and quarantine measures might be required. Unfortunately, confusion about which level of government should take the lead often occurs, thus revealing the ability of quarantine pow- 
ers to spotlight difficulties federalism poses for public health. The Speaker case illustrates the complexities federalism presents because the episode involved local, state, and federal authorities in the effort to try to ensure that Speaker did not pose a public health threat.

\section{State Authority for Isolation and Quarantine}

State governments derive isolation and quarantine authority within their borders from the police power ${ }_{2}^{24}$ and all states have such powers, although actual laws vary significantly. In many cases, disparate legal regimes pose no problem for the exercise of quarantine powers, but lack of uniformity can adversely affect coordination between local, state, and federal officials. Typically, public health detention powers are found in laws that address sexually transmitted diseases, ${ }^{25} \mathrm{~TB},{ }^{26}$ and other communicable diseases. ${ }^{27}$ When a novel disease emerges, states sometimes find they lack legal power to act, as occurred with severe acute respiratory syndrome (SARS), because their laws have not expressly authorized action for the emerging threat. ${ }^{28}$ This problem has highlighted how many state laws on isolation and quarantine are antiquated scientifically and in their protection of civil liberties. ${ }^{29}$ The need to consider the exercise of quarantine powers more seriously has exposed aspects of the relationship between law and public health, particularly its neglect.

Recent threats have, however, forced state governments to review their quarantine powers. President Bush stressed, for example, the need for states to analyze their isolation and quarantine laws as a homeland security priority. ${ }^{30}$ The review process has included nearly 40 states adopting, in whole or in part, the Model State Emergency Health Powers Act (Model Act), which was drafted after the anthrax attacks in 2001 in order to provide states with a tool with which to assess their legal preparedness for public health emergencies. A controversial aspect of the Model Act centered on its compulsory powers provisions, which revealed the power of isolation and quarantine measures to concentrate political and legal attention on public health challenges. The importance of the legal review and reform processes has been underscored since 2001 through events such as the SARS outbreak and legal preparedness activities related to pandemic influenza. The imposition of an isolation order on Speaker has again stimulated states to scrutinize their isolation and quarantine laws.

\section{Federal Authority for Isolation and Quarantine} Questions about isolation and quarantine measures also reveal substantive and procedural problems in federal law. The federal government's isolation and quarantine authorities are contained in the Public Health Service Act, ${ }^{31}$ which grants the Secretary of DHHS authority to make and enforce regulations to prevent the introduction, transmission, or interstate spread of communicable diseases into or within the United States and to apprehend, detain, or conditionally release individuals infected with "quarantinable diseases" specified by executive order..$^{32}$ The president has, to date, identified cholera, diphtheria, infectious $\mathrm{TB}$, plague, smallpox, yellow fever, viral hemorrhagic fevers (e.g., Lassa, Marburg, Ebola, Crimean-Congo, South American), SARS, and pandemic influenza as quarantinable diseases under federal law. ${ }^{33}$ The federal government can enforce isolation and quarantine measures by criminal sanctions or judicial injunction. ${ }^{34}$

The Speaker case exposed problems with federal isolation and quarantine authorities. For example, federal powers apply to a specific list of diseases, thus depriving the federal government of flexibility when responding to novel threats. The listing approach requires the president, for each new threat, to make the disease quarantinable through executive order, which is what transpired when SARS and fears of pandemic influenza emerged. Federal law also fails to authorize the federal government to use a range of measures, including individual screening, contact tracing, and DOT, all of which may be useful in dealing with disease threats, including MDR-TB and XDR-TB. Finally, federal law does not include appropriate due process protections because it does not give individuals subject to isolation or quarantine orders a right to a fair hearing. The Constitution requires an impartial hearing for persons under civil confinement or detention, ${ }^{35}$ including those infected with TB. ${ }^{36}$ Current federal quarantine authority is, therefore, arguably unconstitutional.

\section{Constitutional and Judicial Review of Isolation and Quarantine Actions}

The Constitution does not mention isolation or quarantine. However, in discussing imports and exports, it recognizes the right of states to execute inspection laws, which are incident to the exercise of quarantine powers. ${ }^{37}$ In 1824, Chief Justice Marshall suggested that states have authority to quarantine under their police powers. ${ }^{38}$ Since Marshall's time, courts have upheld the exercise of compulsory detention powers for public health purposes. ${ }^{39}$ This jurisprudence reveals deference by the courts, which usually regarded isolation or quarantine actions as presumptively valid. Judicial activity in U.S. public health has primarily been driven by challenges mounted against the exercise of quarantine powers during epidemics, notably TB. ${ }^{40}$ 
In these cases, the judiciary asserted some control over isolation and quarantine measures. Following the "rule of reasonableness" established in Jacobson $v$. Massachusetts, courts insisted that use of quarantine powers be justified by "public necessity," and that states may not act "arbitrarily" or "unreasonably." ${ }^{11}$ Courts have also set four limits on isolation and quarantine authority:

1. The Subject Must Be Actually Infectious or Have Been Exposed to Infectious Disease. Health authorities must demonstrate that individuals are infected or were exposed to disease and, thus, pose a public health risk. ${ }^{42}$ Courts have been reluctant to stigmatize citizens in the absence of reasonable proof. ${ }^{43}$ Thus, isolation of persons with TB must demonstrate that they are infectious, or would be infectious if they stopped taking their medication.

2. Safe and Habitable Conditions. Courts periodically insisted on safe and healthful environments for those subject to isolation or quarantine because public health powers are designed to promote well-being, and not to punish. ${ }^{44}$ The Supreme Court held, for example, that civilly committed mental patients have a right to "conditions of reasonable care and safety," "freedom from bodily restraint," and "adequate food, shelter, clothing and medical care." ${ }^{45}$

This requirement is germane to the case of Robert Daniels, an XDR-TB patient who has been compulsorily isolated in the "jail" section of a hospital in Maricopa County, Arizona. The American Civil Liberties Union filed suit arguing that Maricopa County denied Daniels constitutionally required habitable conditions because he is regularly stripped searched, not allowed to exercise or go outside, and denied basic amenities such as regular visits and access to a telephone. ${ }^{46}$ While this lawsuit was pending, Maricopa County transferred Daniels to NJMC, where Speaker was being treated.

3. Justice and Non-Discrimination. A federal court struck down one of the most invidious measures in public health history in Jew Ho v. Williamson. ${ }^{47}$ At the turn of the 20th century, public health officials quarantined an entire district of San Francisco, ostensibly to contain an epidemic of bubonic plague, but the quarantine operated exclusively against the Chinese community. The federal court held the quarantine unconstitutional because health authorities acted with an "evil eye and an unequal hand." 48 Jew Ho forms part of the leitmotif noted earlier - that governments are sometimes tempted to use their quarantine powers as an instrument of prejudice against vulnerable individuals or populations. ${ }^{49}$ This theme informed controversies that arose during MDR-TB outbreaks in the 1990s when New York and other cities targeted the mentally ill, drug addicts, and homeless persons for DOT, while affluent groups were spared. ${ }^{50}$

The Supreme Court has described civil commitment as a "massive curtailment of liberty." Although civil commitment cases often concern the mentally ill, the principles these cases enunciate also apply to isolation and quarantine measures. As one court explained in the context of $\mathrm{TB}$, " $[\mathrm{I}]$ nvoluntary commitment for having communicable tuberculosis impinges on the right to liberty, full and complete liberty, no less than involuntary commitment for being mentally ill." ${ }^{2}$ Some courts have required actual danger to the public as a condition of civil confinement in both mental health ${ }^{53}$ and infectious disease ${ }^{54}$ contexts. For example, in the case of In re City of Nere York $v$. Doe, the court required clear and convincing evidence of the person's inability to complete a course of TB medication before permitting compulsory restraint. ${ }^{55}$

Given the strict standard of review, courts could require the government to demonstrate that there are no less restrictive alternatives to achieve the public health objective. ${ }^{56}$ The government might have to offer, for example, DOT as a less restrictive alternative to isolation. However, the government does not have to go to extreme, or unduly expensive, means to avoid confinement ${ }^{57}$ because the judiciary is not likely to require the state to provide economic incentives and benefits to induce compliance. In the TB context, New York City health officials argued that they could not be required "to exhaust a pre-set, rigid hierarchy of alternatives that would ostensibly encourage voluntary compliance....regardless of the potentially adverse consequences to the public health." 58

4. Procedural Due Process. Persons subject to detention are entitled to procedural due process. As the Supreme Court recognized, "[T] $[$ here can be no doubt that involuntary commitment to a mental hospital, like involuntary confinement of an individual for any reason, is a deprivation of liberty which the State cannot accomplish without due process of law." 59 The procedures required depend on the nature and duration of the restraint. ${ }^{60}$ Certainly, the government must provide elaborate due process for long-term, non-emergency, detention. ${ }^{61}$ Noting that "civil commitment for any purpose constitutes a significant deprivation of liberty," 62 and that commitment "can engender adverse social consequences," the Supreme Court has held that, in a civil commitment hearing, the government has the burden of proof by "clear and convincing evidence."63

In Greene v. Edwards, the West Virginia Supreme Court held that persons with infectious TB are entitled to similar procedural protections as persons with mental illness facing civil commitment. ${ }^{64}$ These safe- 
guards include the right to counsel, a hearing, and an appeal. The invasion of liberty occasioned by detention, the implications of erroneously finding a person dangerous to the public's health, and the value of procedures in determining complex facts justify rigorous procedural protections.

The limits courts have placed on government use of isolation and quarantine reflect not only the threat posed by pathogenic microbes but also the rule of adapt and respond more rapidly to novel threats. This empowerment has the corresponding effect, under the rule of law, of heightening scrutiny of how the federal government exercises such broader powers.

2. Due Process. The proposed regulations empower federal public health officers to quarantine ill passengers provisionally for up to three business days. Thereafter, officers can order full quarantine on grounds of a reasonable belief that a person or group is in the quali-

\section{Civil libertarians draw attention to the substantial personal interests affected by isolation and quarantine actions. Individuals subjected to confinement lose their liberty, suffer invasions of individual rights (including loss of privacy), face stigma because their community is aware of the infectious danger they pose, may have their bodily integrity compromised because of compulsory treatment, and endure socio-economic burdens such as the loss of income during their detention, and possibly thereafter.}

law. Whether and how isolation and quarantine are applied reveals aspects of politics, economics, and cultures in many societies. The relationship of quarantine powers to the rule of law is similarly instructive about governance strategies to balance individual rights and the public good. Jurisprudence on isolation and quarantine reveals a way of thinking about how political power should be, at each step, subject to legal rules and procedures.

\section{Revising Federal Law: The Proposed New Federal Quarantine Regulations}

Having effective public health powers operating within the rule of law encourages constant re-evaluation of legal rules and procedures, and the exercise of quarantine powers provides a powerful way to stimulate interest in such re-assessment. In keeping with this dynamic, and recognizing the problems with existing federal quarantine powers, the DHHS proposed new regulations in $2005,{ }^{65}$ which provide another opportunity to evaluate how quarantine powers can protect public health within the rule of law.

1. Scope of Federal Power. The Public Health Service Act authorizes the "apprehension, detention, or conditional release" of individuals for diseases listed by executive order. The proposed regulations would broaden the scope of federal power because they define "ill person" to include the conditions linked with quarantinable diseases, such as fever, rash, persistent cough, or diarrhea. This approach embodies an important shift that allows the federal government to fying stage of a quarantinable disease. The length of quarantine may not exceed the period of incubation and communicability, which can range from weeks to months, as in the case of XDR-TB. During quarantine, officers can offer individuals prophylaxis or treatment, but a refusal can result in continued deprivation of liberty.

Under the revised regulations, the federal government does not intend to provide individuals with hearings during provisional quarantine, but individuals can request an administrative hearing to contest a full isolation or quarantine order. Interestingly, the federal government offered Speaker the right to a hearing in connection with its isolation order, a right not found in the federal quarantine regulations (FQR) that applied to Speaker. It appears as if the federal government sought guidance on the right to a hearing from the proposed revisions to the FQR, which suggests recognition of the constitutionally suspect lack of due process in the existing regulations.

The administrative process in the proposed FQR includes a hearing that comports with elements of due process: notice, hearing before a public official, and right of communication with counsel. Still, deficiencies remain: (1) individuals must request a hearing, which may delay or prevent independent review for those who do not understand or take the initiative; (2) the proceedings can be informal, even permitting hearings based exclusively on written documents; and (3) the hearing officer may be a federal public health employee who makes a recommendation to the CDC 
Director. The European Court of Human Rights found a similar scheme in violation of Article 5 of the European Convention on Human Rights, which requires a hearing by a "court." 66

As of this writing, the federal government has not adopted the proposed revisions to the FQR. The public health community supported many proposed revisions, but critics worried about invasions of liberty, privacy, and property that the revised regulations would arguably produce. Due process experts disliked the lack of any hearing for provisional isolation or quarantine and the failure to provide more robust due process for those subject to full isolation or quarantine orders. Privacy advocates worried that the proposed regulations would undermine the protection of an individual's personal and health information. The travel industry criticized the costs the proposed rules would impose on it to collect, protect, and transmit passenger information.

The Speaker case has re-focused attention on the unadopted revision of the FQR and may, thus, contribute to new efforts by the federal government to update this fundamental set of federal public health laws. Whether the Speaker incident proves a powerful catalyst for such a significant change remains to be seen.

\section{The Ethics of Involuntary Detention of Persons with Infectious TB}

Civil libertarians draw attention to the substantial personal interests affected by isolation and quarantine actions. Individuals subjected to confinement lose their liberty, suffer invasions of individual rights (including loss of privacy), face stigma because their community is aware of the infectious danger they pose, may have their bodily integrity compromised because of compulsory treatment, and endure socio-economic burdens such as the loss of income during their detention, and possibly thereafter. These issues are important individual interests, and state and federal governments should do all they can to mitigate these harms, as well as ensure that they exercise quarantine powers in accordance with the rule of law.

From an ethical perspective, the fact that detention is a drastic measure does not mean that isolation and quarantine are inappropriate. Persons with infectious, or potentially infectious, TB pose a risk to the public. $\mathrm{TB}$ can be spread by airborne droplets among persons congregated in confined spaces for extended durations, including long-haul travel in a bus, metro, train, or plane, as well as in group settings such as mental institutions, hospitals, nursing homes, and homeless shelters. Consequently, detention may be ethically justifiable, and provided that it is necessary, it is used as a last resort and applied in keeping with notions of human dignity and natural justice.

Speaker's case is an example of an ethically appropriate exercise of isolation powers. He had infectious TB. Whether his infectious TB was XDR-TB, as previously thought, or MDR-TB, as eventually diagnosed, does not change the ethical (or the epidemiological) analysis. Public health authorities first attempted less restrictive measures, such as treatment combined with "no travel" instructions, but twice Speaker did not comply and put the health of others at risk. Further, the federal government offered Speaker the opportunity to exercise his right to a hearing, a right guaranteed by the Constitution if not the existing FQR. In each location of isolation, Speaker has been detained in highly therapeutic, humane facilities. Disagreements about the "facts" of his case ${ }^{67}$ do not change these conditions of ethical confinement: a dangerous infectious condition, less drastic alternatives attempted, procedural due process offered, and humane conditions of isolation.

In the ethical realm, Speaker's behavior raises another facet of the dynamics of isolation and quarantine in modern societies - the responsibility of individuals in the increasingly challenging and dangerous world of public health governance. Isolations of infectious TB patients typically, if not universally, involve failure of the patients to heed instructions concerning treatment or interacting with other persons. ${ }^{68}$ Government officials do not today blow the ram's horn to warn of contagious disease in the community, but warnings about appropriate individual behavior are given in ways that trigger ethical, if not legal, responsibilities of citizens to do no harm to others.

\section{Beyond Quarantine: Global Dimensions of the Speaker Incident and Drug-Resistant Tuberculosis}

Although the exercise of quarantine powers made the Speaker incident a window on public health ethics, law, and governance, the incident involved other features that deserve mention. In particular, the Speaker case was international in scope and implications, which draws attention to the global dimensions of this incident and the problem of drug-resistant TB. This section considers global facets of the Speaker case.

\section{The Global Dimensions of U.S. Public Health Law} The Speaker case highlighted issues in U.S. public health law related to the international aspects of his travels. Speaker's plans to travel to Europe after being diagnosed with MDR-TB raised the issue about which governmental body can prevent a U.S. 
citizen from leaving the United States. Local, state, and federal public health officials conferred about ways to prevent Speaker's international travel, but he had already left the country. While local and state powers are still relevant, the international context of foreign travel suggests that the relevant constitutional level of government to prevent persons with dangerous, contagious pathogens from traveling internationally from the United States is the federal government. Federal law presently does not contain provisions relating to preventing disease exportation; rather, the focus is on preventing or addressing disease importation. ${ }^{69}$ Existing statutory law and the proposed revisions to the FQR do not address the need to empower the federal government to prevent persons who pose a public health risk from traveling outside the country.

A second international issue centered on the federal government's attempts to convince Speaker to report to Italian public health authorities after the CDC made the XDR-TB diagnosis. Did the federal government have the legal authority to enforce quarantine powers on U.S. nationals present in the territory of other nations? Generally, the federal government cannot enforce federal law outside the United States unless Congress intended for the law in question to have such extraterritorial effect, ${ }^{70}$ and no such intent can be located in federal public health law. In fact, Congress prescribed that the FQR shall be applicable only to individuals coming into a state or possession of the United States from a foreign country or possession. ${ }^{71}$

The U.S. border guard's failure to detain Speaker upon his re-entry into the United States, despite the border guard knowing of the CDC's health alert, has generated concerns about the inability of U.S. border control systems to handle public health threats. These concerns existed prior to the Speaker incident, as illustrated by an Institute of Medicine study on the system of quarantine stations at U.S. ports of entry. ${ }^{2}$ The study argued that this system "no longer protect[s] the US population against microbial threats of public health significance that originate abroad." 73 Improving public health capabilities at U.S. borders requires improved leadership, laws and regulations, infrastructure, training, interagency collaboration, and funding. How Speaker's re-entry into the United States was handled indicates both some progress (e.g., the CDC health alert reached the border control personnel in time to detain Speaker) and continuing problems (e.g., Speaker was allowed into the country without compliance with the health alert) that require more political commitment and financial resources from Congress.
Drug-Resistant Tuberculosis and the New International Health Regulations

The World Health Assembly adopted the revised International Health Regulations in May 2005 (IHR 2005), ${ }^{74}$ and the Speaker incident intersected with this new international agreement immediately before the IHR 2005 entered into force on June 15, 2007. The IHR 2005 appeared in three ways in the Speaker case. First, the federal isolation order against Speaker connected to ongoing debate about whether compulsory measures may increasingly be needed to contain the global spread of XDR-TB. The IHR 2005 acknowledges that isolation and quarantine may be required, but the regulations oblige States Parties to implement compulsory measures consistently with scientific, public health, and human rights principles. In that regard, the WHO has issued guidance on involuntary detention for XDR-TB control in light of human rights norms. ${ }^{75}$

Second, although the IHR 2005 was not yet in force, the United States formally notified the WHO that the Speaker situation may constitute a public health emergency of international concern (PHEIC) pursuant to the IHR 2005..$^{6}$ This action connected to debates within the WHO about whether XDR-TB cases could trigger the IHR 2005's notification obligations by being disease events that might constitute a PHEIC. Prior to the Speaker incident, a WHO task force asserted that XDR-TB is not a PHEIC because notification of such an emergency is "only intended for outbreaks of acute disease, rather than the 'acuteon-chronic' situation of...XDR-TB." 77 Alarm about the XDR-TB problem suggests that this pathogen is dangerous and is of global concern, perhaps creating the need for State Parties to the IHR 2005 to follow the U.S. lead in viewing this pathogen within the scope of the surveillance obligations of the regulations.

Third, CDC Director Julie Gerberding drew attention to the IHR 2005 in comments to the press about the Speaker episode. Gerberding stated that the IHR 2005 contained "wonderful statements of principles" but do not provide "operational details of things like who should pay to move a patient, or who should care for a patient." ${ }^{8}$ She also stated, "I think a central question that we will be grappling with is, whose patient is it?"79

These comments about the IHR 2005 require scrutiny. The IHR 2005 was never designed to answer the kinds of questions Gerberding raised. In addition, the application of general principles of international law answers these questions. Under the principle of sovereignty, the country in which a patient is physically located has primary responsibility for public health activities and persons within its territory and jurisdic- 
tion. Under the principle of non-intervention in the domestic affairs of states, the home country of a patient has no right to intervene in the sovereign affairs of the host country concerning public health.

These principles mean that, in Speaker's case, Italy had primary responsibility for public health vis-à-vis Speaker when he was physically present in Italy, and that the United States could ask, but not legally require, that Italy undertake certain actions regarding Speaker. Absent a specific treaty obligation, Italy was under no duty to transport Speaker back to the United States or pay for such transport. If the United States wanted to transport him home, then the United States would be responsible for the costs of such transport. Under international law, no confusion existed about whose patient Speaker was while he was in Italy, or what country had to pay to transport him home.

Easy legal answers do not, of course, produce funds and capabilities to transport a U.S. citizen thought to be infected with XDR-TB back to the United States, particularly when federal agencies had no plans or resources to execute such an action. Whether and how to generate such funds and capabilities are, however, national policy questions not issues of international law or lacunae in the IHR 2005.

\section{The Global Problem of Drug-Resistant Tuberculosis} In many ways, Speaker is an atypical victim of infection by drug-resistant TB. As the statistics about XDR-TB suggest, the typical XDR-TB patient is not white, affluent, highly educated, well traveled, and media savvy. The change in Speaker's diagnosis from XDR-TB to MDR-TB does not lessen the problems both forms of drug-resistant TB present to population health, particularly those in transition and developing countries with high rates of HIV/AIDS and weak to non-existent public health systems. The "looking glass" quarantine powers provide for examining public health law, governance, and ethics generates much less guidance when contemplating how to respond to the global march of drug-resistant TB. The task list for altering this trajectory is formidable: improve surveillance for drug-resistant TB; craft better non-pharmacological interventions that protect population health and respect individual rights; develop more accurate diagnostic technologies to improve the ability to distinguish MDR-TB from TB and XDR-TB from MDRTB; control the synergy between HIV/AIDS and TB more effectively; invent new antibiotic treatments; and build health infrastructure capacity to handle these tasks. How these tasks will be accomplished is something on which neither the Speaker case nor the quarantine looking glass provides much insight.

\section{Conclusion}

In all likelihood, the Speaker episode will enter the annals of public health history as a case involving an incredible set of facts and sequence of events, as well as deeper implications for public health and the governance systems, legal rules, and ethical principles that support this policy endeavor. This article focused on how the use of federal quarantine power against Speaker connects to, and helps illustrate, the ways in which isolation and quarantine reveal features about the place of public health in the politics, economics, cultures, and governance philosophies of societies.

The Speaker case teaches valuable lessons about challenges public health governance confronts from the individual to the global level, especially in the context of a pathogen increasingly resistant to the tools of modern medicine. Speaker's odyssey focused attention on the threat XDR-TB and MDR-TB present, but heightened awareness is not a policy response. An episode at the end of July 2007 involving two persons infected with drug-resistant TB who ignored instructions from Taiwanese authorities not to travel and flew from Taiwan to China anyway ${ }^{80}$ is a reminder that the individual, national, and international governance challenges that Speaker's case highlighted have not disappeared as his story fades from the front pages.

Speaker's case also provides lessons on the importance of public health law on isolation and quarantine because, like the threats of bioterrorism and pandemic influenza, this case forced another round of scrutiny of state, federal, and international legal rules that relate to compulsory measures. This case emphasizes the need for the federal government to finalize its proposed revision of the FQR in such a way that the new regulations provide a stronger basis for federal action in the future. The trajectory of drug resistance in $\mathrm{TB}$ will, in all likelihood, confront public health officials with the need to consider compulsory measures for individuals infected with highly dangerous and contagious pathogens. Public health principles and the rule of law encourage the crafting of the best possible legal framework before more threats emerge.

Finally, Speaker's case illustrates the limits of public health law and the importance of ethical obligations in communicable disease contexts permeated with danger, uncertainty, and fear. Public health's reliance on voluntary compliance with treatment and travel instructions involving TB patients depends on such patients understanding the public health consequences of their behavior. The likelihood of increased cases of drug-resistant TB only heightens the individual's ethical role in public health governance.

With respect to public health governance, law, and ethics, what the quarantine looking glass reveals has 
changed over time. Through this looking glass, we see how societies cope with transformations in scientific understandings of pathogenic threats and political commitments to individual rights. But these changes, and the historical distance between the first Venetian lazeretto and Speaker's isolation, do not diminish what we can learn from the focus quarantine powers bring to bear on our political, social, and personal understandings of population and individual health.

\section{References}

1. Centers for Disease Control and Prevention, "Tuberculosis: General Information, July 2007," available at <http://www. cdc.gov/tb/pubs/tbfactsheets/tb.htm> (last visited September 19, 2007); Centers for Disease Control, "Multi-Drug Resistant Tuberculosis (MDR-TB), July 2007," available at <http://www. cdc.gov/tb/pubs/tbfactsheets/mdrtb.htm> (last visited September 19,2007 ).

2. Centers for Disease Control and Prevention, "Extensively DrugResistant Tuberculosis (XDR-TB), July 2007," available at <http://www.cdc.gov/tb/pubs/tbfactsheets/xdrtb.htm> (last visited September 19, 2007).

3. World Health Organization, "XDR-TB Update 2006: Message from the WHO Director of Stop TB, Dr. Mario Raviglione," available at <http://www.who.int/tb/xdr/dir_stb_message 25sep06/en/index.html > (last visited September 19, 2007).

4. World Health Organization, "Emergence of XDR-TB," available at <http://www.who.int/mediacentre/news/notes/2006/np23/ en/index.html> (last visited September 19, 2007).

5. See, e.g., J. A. Singh, R. Upshur, and N. Padayatchi, "XDR-TB in South Africa: No Time for Denial or Complacency," PLoS Medicine 4, no. I (2007): e50, available at <http://www.pubmedcentral.nih.gov/articlerender.fcgi?artid $=1779818>$ (last visited September 19, 2007).

6. World Health Organization, "WHO Guidance on Human Rights and Involuntary Detention for XDR-TB Control, Jan. 24, 2007," available at <http://www.who.int/tb/xdr/involuntary_treatment/en/index.html $>$ (last visited August 14, 2007) [hereinafter cited as WHO].

7. This description of the Speaker case is taken from a number of sources, including the Centers for Disease Control and Prevention, "Interim Timeline: Actions to Protect Public Health - Investigation of U.S. Traveler with XDR TB," available at <http://www.cdc.gov/tb/XDRTB/timeline.htm> (last visited August 14, 2007) and J. L. Gerberding, Director, Centers for Disease Control and Prevention, Recent Case of Extensively Drug Resistant TB: CDC's Public Health Response, Testimony before the Committee on Appropriations Subcommittee on Labor, Health and Human Services, and Education, U.S. Senate, June 6, 2007, available at <http://www.cdc.gov/washington/testimony/6-06-07_XDR_TB_testimony.html> (last visited September 19, 2007).

8. See, e.g., C. F. Mullet, "A Century of English Quarantine, 17091825," Bulletin of the History of Medicine 23, no. 6 (1949): 527-45; G. Rosen, A History of Public Health (New York: MD Publications, 1958); O. P. Schepin and W. V. Yermakov, eds., International Quarantine (Madison, CT: International Universities Press, 1991): at 125-58; C.-E. Winslow, The Conquest of Epidemic Disease: A Chapter in the History of Ideas (New York: Hafner, 1967).

9. F. H. Garrison, A History of Medicine, 4th ed. (Philadelphia: W. B. Saunders, 1928): at 60 . There are many doctrines for avoiding contagion in the Five Books of Moses. For a useful description, see id., at 67-70; Winslow, supra note 8, at 79-82; E. Lieber, "Skin Diseases: Contagion and Sin in the Old Testament," International Journal of Dermatology 33, no. 8 (1994): 593-95.

10. Hippocrates, Nature of Man (chap. 9), in G. E. R. Lloyd, ed., Hippocratic Writings (London: Penguin, 1978): at 266; Thucy- dides, The Peloponnesian Wars (New York: Penguin, 1978). Analysis of the concept of infection as understood by the ancient Greeks is offered by O. Temkin, "An Historical Analysis of the Concept of Infection," in O. Temkin, The Double Face of Janus and Other Essays in the History of Medicine (Baltimore: Johns Hopkins University Press, 1977): at 456-71.

11. See Winslow, supra note 8 , at 74 .

12. W. W. Ford, "A Brief History of Quarantine," Johns Hopkins Hospital Bulletin 25 (1914): 80-86; W. H. McNeill, Plagues and Peoples (Garden City, NY: Doubleday/Anchor, 1976): at 124-35.

13. G. E. Rothenberg, "The Austrian Sanitary Cordon and the Control of the Bubonic Plague: 1710-1871," Journal of the History of Medicine and Allied Sciences 28, no. 1 (1973): 15-23.

14. N. Howard-Jones, "Origins of International Health Work," British Medical Journal (May 6, 1950): 1032-37.

15. D. P. Fidler, International Law and Infectious Diseases (Oxford: Clarendon Press, 1999): at 35-42.

16. See Schepin and Yermakov, supra note 8, at 9-27; Rothenberg, supra note 13; N. Howard-Jones, "The Scientific Background of the International Sanitary Conferences, 1851-1938," WHO Chronicle 28 (1974): 229-47, 369-84, 414-26, 455-70, 495-508.

17. See Fidler, supra note 15, at 21-57.

18. D. F. Musto, "Quarantine and the Problem of AIDS," Milbank Quarterly 64, Supplement I (1986): 97-117, at 98.

19. Id., at 106 .

20. D. L Heymann, ed., Control of Communicable Diseases Manual, 18th ed. (Washington, D.C.: American Public Health Association, 2004): at 621 .

21. Id., at 617-19.

22. R. Coker, "Just Coercion? Detention of Nonadherent Tuberculosis Patients," Annals of the New York Academy of Science 953b, no. 1 (2001): 216-23.

23. L. O. Gostin, Public Health Law: Power, Duty, Restraint, 2nd ed. (New York/Berkeley: Milbank Memorial Fund and University of California Press, forthcoming 2008).

24. Gibbons v. Ogden, 22 U.S. 1, 25 (1824); Hennington v. Georgia, 163 U.S. 299 (1896).

25. National Conference of State Legislatures, Sexually Transmitted Diseases: A Policymaker's Guide and Summary of State Laws (Denver: National Conference of State Legislators, 1998): at 85-91.

26. H. Markel, When Germs Travel: Six Major Epidemics That Have Invaded American Since 1900 and the Fears They Unleashed (New York: Pantheon Books, 2005): at 13-46; L. O. Gostin, "Controlling the Resurgent Tuberculosis Epidemic: A Fifty State Survey of Tuberculosis Statutes and Proposals for Reform," JAMA 269, no. 2 (1993): 256-61.

27. L. O. Gostin, S. Burris, and Z. Lazzarini, "The Law and the Public's Health: A Study of Infectious Disease Law in the United States," Columbia Law Review 99, no. 1 (1999): 59-118.

28. National Conference of State Legislatures, "Overview of State Public Health Preparedness," January 28, 2002, avail. able at <http://www.ncsl.org/programs/press/2002/snapshot. htm \#quarantine $>$ (last visited September 19, 2007).

29. D. S. Reich, "Modernizing Local Responses to Public Health Emergencies: Bioterrorism, Epidemics, and the Model State Emergency Health Powers Act," Journal of Contemporary Health Law and Policy 19, no. 2 (2003): 379-414.

30. White House, National Strategy for Homeland Security, July 2002, available at <http://www.whitehouse.gov/homeland/ book/nat_strat_hls.pdf> (last visited September 19, 2007).

31. 42 U.S.C. $\$ \$ 264-272(2005)$

32. 42 U.S.C. $\$ 264$ (2005).

33. Executive Order no. 13,295, Revised List of Quarantinable Communicable Diseases, April 4, 2003, available at <http:// www.cdc.gov/ncidod/sars/executiveorder040403.htm> (last visited September 19, 2007); Executive Order: Amendment to Executive Order no. 13,295, Relating to Certain Influenza Viruses and Quarantinable Communicable Diseases, April 1, 2005, available at <http://www.whitehouse.gov/news/relea 
ses/2005/04/20050401-6.html> (last visited September 19, 2007).

34. 42 U.S.C. $\$ 271$ (2005); 28 U.S.C §1331 (2005).

35. O'Connor v. Donaldson, 422 U.S. 563,580 (1975)

36. Greene v. Edwards, 263 S.E.2d 661 (W. Va.1980).

37. U.S. Constitution, art. I, \$10, cl. 2. See Brown v. Maryland, 25 U.S. (12 Wheat.) 419 (1827); W. Cowles, "State Quarantine Laws and the Federal Constitution," American Law Review 25, no. 1 (1891): 45-53.

38. See Gibbons, supra note 24 , at 205 .

39. D. J. Merritt, "The Constitutional Balance Between Health and Liberty," Hastings Center Report 16, no. 6 (1986): S2-S10; D. J. Merritt, "Communicable Disease and Constitutional Law: Controlling AIDS," New York University Law Review 61, no. 5 (1986): 739-99.

40. See Greene, supra note 36 (requiring the same due process for TB detention as for civil commitment for mental illness); In re Halko, 54. Cal. Rptr. 661 (Cal. Ct. App. 1966) (upholding detention for TB); Jones v. Czapkay, 6 Cal. Rptr. 182 (Cal. Ct. App. 1960) (refusing to find county health officials liable for secondary case of TB after initial case left quarantine); White v. Seattle Local Union No. 81, 337 P.2d 289 (Wash. 1959) (holding that union did not wrongfully remove officer who was confined for TB).

41. Jacobson v. Massachusetts, 197 U.S. 11 (1905).

42. Smith v. Emery, 42 N.Y. Supp. 258, 260 (1896) ("The mere possibility that persons may have been exposed to disease is not sufficient.... They must have been exposed to it, and the conditions actually exist for a communication of the contagion."); Arkansas v. Snow, 324 S.W.2d 532 (Ark. 1959) (holding that commitment for TB treatment requires a finding that the patient is a danger to the public health).

43. See, e.g., State v. Snow, 324 S.W.2d 532, 533 (Ark.1959) (officials have to provide evidence of active TB to justify involuntary commitment).

44. Kirk v. Wyman, 65 S.E. 387, 391 (S.C. 1909) ("even temporary isolation in [a pesthouse] would be a serious affliction"). Souvannarath v. Hadden, 116 Cal. Rptr. 2d 7 (Cal. Ct. App. 2002) (upholding state law forbidding detainment of noncompliant MDR-TB patient in a jail); Benton $v$. Reid, 231 F.2d 780 (D.C. Cir. 1956) (persons with infectious disease are not criminals and should not be detained in jails); but see Ex parte Martin, 188 P.2d 287 (Cal. 1948) (upholding quarantine in county jail despite the fact that it was overcrowded and had been condemned).

45. Youngberg v. Romeo, 457 U.S. 307, 315, 319, 324 (1982). See also City of Milwaukee v. Ruby Washington, Supreme Court of Wisconsin, 2007 WI 104, July 17, 2007, available at <http:// www.wicourts.gov/sc/opinion/DisplayDocument.html?content =html\&seqNo=29744 $>$ (last visited September 19, 2007) (holding that Wisconsin law authorizes "confinement to a jail...provided the jail is a place where proper care and treatment will be provided and the spread of disease will be prevented").

46. A. Kairi, "ACLU Brings Suit Against Arizona for Quarantine of Tuberculosis Patient: Robert Daniels Reportedly Strip Searched Regularly and Denied Visits with Family," June 1, 2007, available at <http://www.associatedcontent.com/article/265889/aclu_brings_suit_against_arizona_for.html> (last visited September 19, 2007).

47. Jew Ho v. Williamson, 103 F.10 (C.C.N.D. Cal. 1900).

48. Id., at 24.

49. D. Markovits, "Quarantines and Distributive Justice," Jourmal of Law, Medicine छ Ethics 33, no. 2 (2005): 323-44.

50. N. N. Dubler, R. Bayer, and S. Landeshan et al., The Tuberculosis Revival: Individual Rights and Societal Obligations in a Time of AIDS (New York: United Hospital Fund, 1992).

51. Vitek v. Jones, 445 U.S. 480,491 (1980).

52. See Greene, supra note 36, at 663 .

53. See, e.g., Suzuki v. Yen, 617 F.2d 173, 178 (9th Cir. 1980).

54. See Souvannarath, supra note 44, at 11-12 (discussing California statute that requires a finding that a TB patient is both a danger to the public health and substantially unlikely to complete treatment before the patient can be confined for treatment); In re Halko, supra note 40, at 661 (holding that isolation of person with $\mathrm{TB}$ does not deprive a person of due process if the health officer has reasonable grounds to believe he is dangerous).

55. In re City of Nere York v. Doe, 614 N.Y.S.2d 8, 9 (App. Div 1994). See also City of York v. Antoinette R., 630 N.Y.S.2d 1008 (N.Y. Sup. Ct. 1995) (upholding detention for TB treatment upon clear and convincing evidence that less restrictive means would not result in successful treatment).

56. Id. (In re City of New York), at 8; City of Milwaukee, supra note 45. The most developed expression of the right to less restrictive alternatives is in mental health cases. See, e.g., Lessard $v$. Schmidt, 349 F. Supp. 1078 (E.D. Wis. 1972).

57. See City of Milwaukee, supra note 45 (holding that it was appropriate for the courts to consider cost when determining the place of confinement); L. O. Gostin, "The Resurgent Tuberculosis Epidemic in the Era of AIDS: Reflections on Public Health, Law, and Society," Maryland Law Review 54, no. 1 (1995): 1-131.

58. Response to Public Comments Concerning Proposed Amendments to Section 11.47 of the Health Code 7, March 2, 1993.

59. See O'Connor, supra note 35 , at 580 (Chief Justice Berger, concurring).

60. Washington v. Harper, 494 U.S. 210 (1990).

61. See, e.g., In re Ballay, 482 F. 2d 648, 563-66 (D.C. Cir. 1973).

62. Addington v. Texas, 441 U.S. 418. 426 (1979).

63. Id., at 425 .

64. See Greene, supra note 36 , at 661 .

65. Department of Health and Human Services, Control of Communicable Diseases (Proposed Rule), 42 CFR Parts 70 and 71 (November 30, 2005).

66. "Case of $X v$. United Kingdom: Confinement of Persons of Unsound Mind in the United Kingdom," in V. Berger, ed., Case Law of the European Court of Human Rights, Volume I: 19601987 (Dublin: Round Hall Press, 1989): at 167.

67. See, e.g., J. Schwartz, "Tangle of Conflicting Accounts in TB Patient's Odyssey," Nere York Times, June 2, 2007, at Al.

68. See, e.g., City of Milwaukee, supra note 45 (affirming the compulsory isolation of TB patient who failed to follow treatment instructions).

69. 42 U.S.C. $\$ 264$ (2005).

70. Equal Employment Opportunity Commission v. Arabian American Oil Co., 499 U.S. 244 (1991).

71. 42 U.S.C. $\$ 264(2005)$.

72. Committee on Measures to Enhance the Effectiveness of the CDC Quarantine Station Expansion Plan for U.S. Ports of Entry, Quarantine Stations at Ports of Entry: Protecting the Public's Health (Washington, D.C.: National Academies Press, 2006).

73. Id., at 2

74. World Health Organization, Revision of the International Health Regulations, 58th World Health Assembly, May 23, 2005, available at <http://www.who.int/gb/ebwha/pdf_files/ WHA58/WHA58_3-en.pdf> (last visited September 19, 2007).

75. See WHO, supra note 6.

76. See Gerberding, supra note 7, at 9.

77. World Health Organization, Global Task Force on XDR-TB, Update: February 2007, at 5, available at <http://www.who. int/tb/xdr/globaltaskforce_update_feb07.pdf> (last visited September 19, 2007).

78. Quoted in Schwartz, supra note 67, at A1.

79. Quoted in id.

80. Associated Press, "Report: Chinese Officials Locate Taiwan Tuberculosis Patients Who Traveled to China," China Post, July 28, 2007, available at <http://www.chinapost.com.tw/ news/2007/07/28/116356/Report:-Chinese.htm> (last visited September 19, 2007). 